\title{
The influence of land cover data on farm-scale valuations of natural capital
}

\author{
Thomas Burke ${ }^{\mathrm{a},{ }^{*}}$, James Duncan Whyatt ${ }^{\mathrm{a}}$, Clare Rowland ${ }^{\mathrm{b}}$, George Alan Blackburn ${ }^{\mathrm{a}}$, Jon Abbatt ${ }^{\mathrm{c}}$ \\ ${ }^{a}$ Lancaster Environment Centre, Lancaster University, LA1 4YQ, United Kingdom \\ ${ }^{\mathrm{b}}$ Centre for Ecology \& Hydrology, Lancaster Environment Centre, Lancaster University, LA1 4YQ, United \\ Kingdom \\ ${ }^{c}$ LUC, Lancaster Environment Centre, Lancaster University, LA1 4YQ, United Kingdom
}

* Correspondence to: Thomas Burke, Lancaster Environment Centre, Lancaster University, LA1 4YQ, United Kingdom. t.burke2@lancaster.ac.uk

\begin{abstract}
The valuation of natural capital within individual farms could inform environmentally beneficial land use change and form the basis of agricultural subsidy schemes based on the provision of ecosystem services. Land cover extents can be used in a benefit transfer approach to produce monetary valuations of natural capital rapidly and at low cost. However, the methodology has not before been used within individual farms, and the impact of land cover data characteristics on the accuracy of

valuations is uncertain. Here, we apply the approach to five UK farms of contrasting size, configuration and farming style, using three widely available land cover products. Results show that the land cover product used has a substantial impact on valuations, with differences of up to $58 \%$, and the magnitude of this effect varies considerably according to the landscape structure of the farm. At most sites, valuation differences are driven by the extent of woodland recorded in the landscape, with higher resolution land cover products incorporating larger amounts of woodland through inclusion of smaller patches, leading to higher overall valuations. Integrating more accurate land cover data and accounting for the condition, configuration and location of natural capital has potential to improve the accuracy of valuations.
\end{abstract}

Keywords: Ecosystem service valuation, land cover, benefit transfer, agriculture, spatial resolution, thematic resolution

\section{Introduction}

Recognition of the vital importance of natural capital and the ecosystem services it provides has increased in recent years. Natural capital is defined as the elements of nature that provide benefits to humanity, including ecosystems, species, freshwater, land and minerals (Spake et al., 2019; Mace et al., 2015), while ecosystem services can be defined as the contribution of ecosystem structure and function to human wellbeing (Burkhard and Maes, 2017). Efforts to map the spatial distribution of these have grown exponentially since Costanza et al. (1997) presented their seminal study valuing ecosystem services globally (Schägner et al., 2013), and the natural capital concept is now being integrated into planning and policy development. The European Union aims to halt the degradation of ecosystem services in the EU by 2020 (European Commission, 2011), while organisations from across the world continue to join the Natural Capital Coalition (Natural Capital Coalition, 2018). The UK has established the Natural Capital Committee to advise the government on the sustainable use of natural capital (Natural Capital Committee, 2016), and commitments to protecting and growing natural capital and using it as a tool in decision making have been made in the government's 25 year environment plan (Defra, 2018a).

The conservation and enhancement of natural capital assets will necessitate work in agricultural areas. 
Nearly half of the EU's total land area is managed by farms, including arable land and grassland, and other features such as woodland and water that can be found within farms and estates (Eurostat, 2018). Agricultural landscapes therefore encompass large areas of natural capital assets, which provide vital ecosystem services such as carbon sequestration and pollution removal. Within the EU there has been growing concern that agricultural subsidies provided through the Common Agricultural Policy have done little to preserve these assets and the services they provide. It has been argued that these area-based payments do not improve environmental outcomes (Defra, 2018a), and support food production without rewarding the provision of ecosystem services (Committee on Climate Change, 2018). Reforms in 2014 saw the introduction of 'greening', where farmers must implement certain environmentally focused measures or lose up to $30 \%$ of their basic payments. However, it has been argued that these measures, which were diluted from initial proposals, are unlikely to lead to major environmental improvements (Matthews, 2013) and unlikely to benefit biodiversity (Pe'er et al., 2014). The European Court of Auditors (2017) have since concluded that whilst greening adds complexity to the payments system, it is unlikely to provide significant benefits to the environment and climate, and has led to very limited changes in farming practices. The development of new land use policies that reflect and reward the provision of ecosystem services and the conservation and enhancement of natural capital assets have therefore been proposed (Hodge, 2017; Committee on Climate Change, 2018; Defra, 2018b). Importantly, such policies rely on the ability to accurately and objectively quantify the natural capital and value the ecosystem services provided on individual farms and monitor changes over time.

Schägner et al. (2013) reviewed current approaches to mapping ecosystem service values in monetary terms. Most common is the use of land cover data to map the extent of natural capital assets, which are assumed to supply a set of services. The value of these services is then obtained from existing studies (primary valuations) in a value per unit area format. For example, land cover data may be used to identify 1,044 ha of woodland at a site. Existing valuation data may indicate that a hectare of similar woodland provides $\$ 1,826$ worth of benefits to humanity annually through the provision of services such as carbon sequestration and pollution removal, leading to the provision of $\$ 1,906,410$ of services each year (Troy and Wilson, 2006). This process is repeated for other assets identified from land cover data to value the total ecosystem service provision within an area. We refer to this methodology as the land cover and benefit transfer technique.

These primary valuations are themselves obtained through a number of methods. For example, timber production, a provisioning service, may be measured in physical terms as the volume in cubic metres of timber harvested. Stumpage prices (the price paid to harvest a given volume of timber) may then be used as a measure of its monetary value (United Nations, 2014). For other services, the value can be less obvious. For example, the travel cost method may be used where the costs incurred by travelling to a site is used as a proxy for the sites recreational value (Philips, 2017). This however can be time consuming and costly to carry out. By using existing data, the land cover and benefit transfer technique has the potential to allow for the valuation of ecosystem service provision within an area rapidly and at a low cost, and provides an alternative when primary research is not possible or feasible (Troy and Wilson, 2006).

The spatial data that is typically used to support this approach includes land cover maps (Sutton and Costanza, 2002; Dales et al., 2014; Troy and Wilson 2006; Burkhard et al., 2009), classified satellite imagery (Kreuter et al., 2001; Troy and Wilson, 2006; Burkhard et al., 2015) and a combination of multiple layers (Brenner et al., 2010; Troy and Wilson, 2006). However, in most cases, the impacts of the spatial and thematic characteristics of these data on valuations is discussed only in a limited fashion, although they have the potential to be significant (Kandziora et al., 2013). Indeed, many spatially explicit ecosystem service assessments do not even state the resolution at which values are mapped (Schägner et al., 2013). 
To date, studies focused on the measurement and valuation of natural capital in agricultural areas and at a scale appropriate for management and decision-making on individual farms have been limited. The land cover and benefit transfer approach has largely been used to produce valuations across large areas and at coarse spatial resolutions. Costanza et al. (1998) estimated the value of ecosystem services on a global scale. For each of 16 biomes, their areas were combined with the per unit values of up to 17 ecosystem services, averaged from over 100 primary studies. The global nature of this study means these biomes are extremely broad, aggregating together for example African rangeland and British pastures, while the 1 degree spatial resolution of the land cover data used (Matthews, 1983) means whole farms and estates would be assigned a single land cover. These per unit values were subsequently used in Sutton and Costanza (2002) with finer $1 \mathrm{~km} 2$ resolution land cover data, although this is still too coarse to map natural capital assets at a local scale. These broad global valuations compiled by Costanza et al. have also been used in regional scale studies, including Seidl and Moraes (2000) and Kreuter et al. (2001). Alternatively, Brenner et al. (2010) compiled a new database of primary valuations. While the land cover data used in these studies potentially has a high enough spatial resolution to detect farm scale variations, none are focused on agricultural areas. The regions studied are also far beyond the size of a typical British or European farm. Troy and Wilson (2006) mapped ecosystem service values at five locations including Maury Island, Washington, a site covering 2,495 ha. Although comparable in size to farms studied in this paper, the island nature of the site meant most land cover classes used were coastal in nature.

Where valuations have been carried out in a primarily agricultural context, this has involved the use of land cover data, but not benefit transfer, and the valuation of a small selection of services. This includes the use of expert opinions to rate the ability of different land covers to supply ecosystem services in rice cropping regions of southeast Asia (Burkhard et al., 2015), and the use of statistical data such as crop composition and yield to quantify food provision in the Halla-Leipzig region of Germany (Burkhard et al., 2009). In the UK, national natural capital accounts provide valuations for ecosystem services provided by assets including farmland, freshwater and woodland (Connors and Philips, 2017). However, these accounts are not spatially explicit, and do not describe provision in individual farms and holdings. Dales et al. (2014) produced maps of 10 ecosystem services using data from the UK National Ecosystem Assessment (UK National Ecosystem Assessment, 2011). However, rather than providing a monetary valuation, this assessed the importance of eight broad habitats for delivering 16 ecosystem services, with each being assigned a category from "High" to "Low" or not applicable.

Therefore, there is a pressing need for a methodology that is capable of quantifying the monetary value of the provision of ecosystem services within individual farms in a spatially explicit manner. While large scale national or regional studies can reveal general trends and inform broad policy objectives, local, farm scale data is required to implement these. For a farmer to consider natural capital when planning potential changes in land use, or for subsidy payments to be made based on the provision of ecosystem services from within their land, valuations known to be accurate at a local scale are required. The land cover and benefit transfer approach described here is well established and has the potential to produce these valuations in a quick and cost effective way. However, its use within individual farms, and the impact of land cover data on the accuracy of valuations, have yet to be adequately explored.

In this paper, we use the land cover and benefit transfer approach to produce monetary valuations of ecosystem service provision within individual farms. Using three commonly used land cover datasets as inputs in the valuation process, we explore how their differing characteristics impact the valuations produced. Through the use of five farms with contrasting landscape characteristics as case studies, ranging from small to large landholdings and covering livestock and arable farming, we explore how 
the interactions between land cover data and landscape characteristics can influence valuations in different environments. Finally, we explore how the approach could be developed further in order to provide more accurate valuations of ecosystem services.

\section{Materials and methods}

\subsection{Study sites}

The UK was chosen as the study area for this work as it contains farms that vary over a wide range of sizes, landscape configurations and farming styles, while land cover data at a range of thematic and spatial resolutions is available for the country (section 2.2). National natural capital accounts are currently being developed for the UK, which incorporate most of the land cover types found in the country (section 2.5). Furthermore, the UK government has recently proposed an overarching framework for sustaining agriculture and protecting the environment which is based on a natural capital approach (Defra, 2018b); appropriate valuation mechanisms are now required in order to implement this approach at the individual farm scale.

Five farms were chosen as case studies in order to test the applicability of the land cover and benefit transfer approach. Table 1 shows that the five farms cover a range of sizes and types, which are typical of the UK, while Figure 1 shows their distribution and boundaries, which span a range of different landscape characteristics (this is demonstrated further in the results section below).

Table 1: Summary of the key characteristics of the farms studied.

\begin{tabular}{l|l|r|l}
\hline \multicolumn{1}{c|}{ Site } & \multicolumn{1}{|c|}{ Location } & \multicolumn{1}{c|}{$\begin{array}{c}\text { Size } \\
\text { (ha) }\end{array}$} & \multicolumn{1}{c}{ Type } \\
\hline Site 1 & Leven, Fife & 652 & Arable, pasture, forestry \\
Site 2 & Cheviot Hills, Northumberland & 4,897 & Upland sheep farming \\
Site 3 & Penrith, Cumbria & 4,150 & Sheep farming, pasture, some arable \\
Site 4 & Ashbourne, Derbyshire & 315 & Dairy \\
Site 5 & Farnham, Surrey & 900 & Traditional mixed agriculture \\
\hline
\end{tabular}



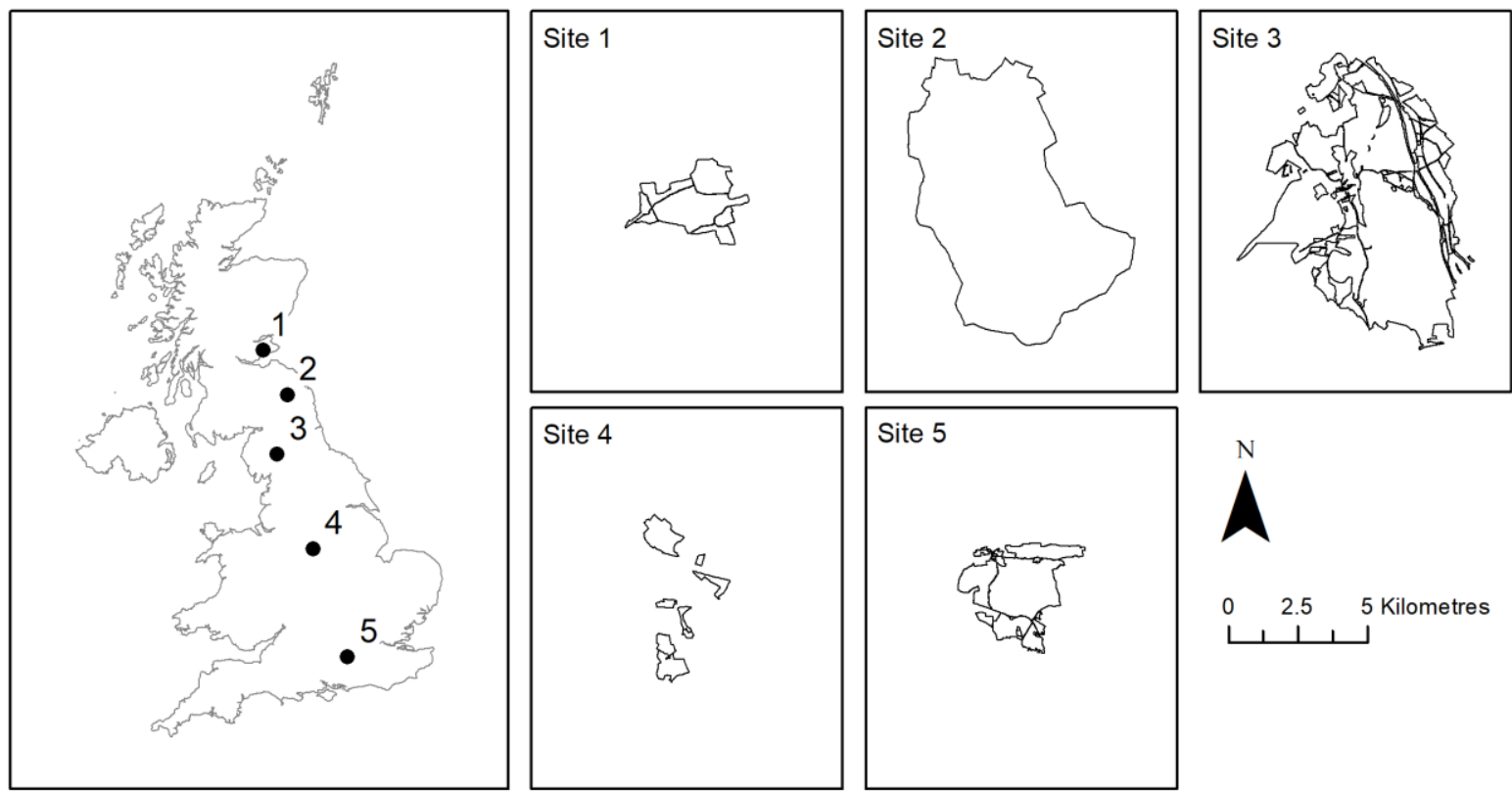

Figure 1: Locations and boundaries of farms used in the study.

\subsection{Land use / land cover data}

For all sites, three land cover data sources were used: the Centre for Ecology \& Hydrology Land Cover Map 2015 (LCM) (Rowland et al., 2017), CORINE Land Cover 2012 (CLC) (Copernicus Programme, 2019) and the European Space Agency Climate Change Initiative Land Cover map 2015 (CCI-LC) (UCL Geomatics, 2017). The characteristics of the three datasets are summarised in Table 2. For each source, the most recent release available was used. 
Table 2: Comparison of the characteristics of the three land cover datasets used.

\begin{tabular}{|c|c|c|c|}
\hline & $\mathbf{L C M}$ & CLC & CCI-LC \\
\hline $\begin{array}{l}\text { Spatial } \\
\text { Resolution }\end{array}$ & $\begin{array}{l}\text { Minimum mappable unit } \\
0.5 \text { ha, minimum feature } \\
\text { width } 20 \mathrm{~m}\end{array}$ & $\begin{array}{l}\text { Minimum mappable unit } \\
25 \text { ha, minimum feature } \\
\text { width } 100 \mathrm{~m}\end{array}$ & 300 m pixels (9 ha) \\
\hline $\begin{array}{l}\text { Spatial } \\
\text { Extent }\end{array}$ & United Kingdom (UK) & Much of Europe & Global \\
\hline $\begin{array}{l}\text { Attribute } \\
\text { Resolution }\end{array}$ & $\begin{array}{l}21 \text { classes, based on UK } \\
\text { Biodiversity Action Plan } \\
\text { Broad Habitats (Jackson, } \\
\text { 2000) }\end{array}$ & $\begin{array}{l}44 \text { classes in a three-level } \\
\text { hierarchy }\end{array}$ & $\begin{array}{l}22 \text { classes, some further } \\
\text { divided with regional } \\
\text { information }\end{array}$ \\
\hline $\begin{array}{l}\text { Classification } \\
\text { Methodology }\end{array}$ & $\begin{array}{l}\text { Random forest classifier, } \\
\text { simplified Ordnance } \\
\text { Survey cartography as } \\
\text { spatial framework }\end{array}$ & $\begin{array}{l}\text { Computer aided manual } \\
\text { interpretation }\end{array}$ & $\begin{array}{l}\text { Pixel classifier. Annual } \\
\text { maps produced by back / } \\
\text { up-dating a baseline map }\end{array}$ \\
\hline Format & Vector, parcel based & Vector, parcel based & Raster, pixel based \\
\hline Access & $\begin{array}{l}\text { Requires license for } \\
\text { vector version }\end{array}$ & Freely available & Freely available \\
\hline Notes & $\mathrm{n} / \mathrm{a}$ & $\mathrm{n} / \mathrm{a}$ & $\begin{array}{l}\text { Urban areas (Pesaresi et } \\
\text { al., 2013; Pesaresi et al., } \\
\text { 2016) and water bodies } \\
\text { (UCL Geomatics, 2017) } \\
\text { largely identified using } \\
\text { external datasets. }\end{array}$ \\
\hline
\end{tabular}

\subsection{Land cover classification system harmonisation}

Each of the three land cover datasets used in this study employs a different classification scheme, with different numbers of output classes that represent different types of land cover. To enable comparisons between datasets, a common classification system was developed. Each of the three land cover maps were reclassified, where necessary by renaming or combing the original classes, to produce a land cover map that had eight 'harmonised' output classes. Table 3 demonstrates how the original classes from the three land cover maps correspond with the harmonised classes.

It has to be recognised that due to the disparate nature of the classification schemes used in each dataset, there are some uncertainties in the correspondence between classes. For example, the CLC Sport and leisure facilities class is part of the Artificial non-agricultural vegetated areas category in the three-level hierarchical CLC classification scheme. This is a land use, rather than land cover class, and includes buildings, infrastructure, or green spaces that are used for sport and leisure. In this study, this class was assigned to the built-up areas harmonised class for comparison purposes, but it may include land covers that could be more appropriately assigned to another class, such as grassland. Similarly, the CLC sparsely vegetated areas class was assigned to bare-areas. The CLC nomenclature guidelines note that this class represents areas where vegetation covers $10-50 \%$ of the 
surface, therefore much of the land surface will be bare earth. However, it is noted that by doing this, the extent of vegetation present will be underestimated. Due to their broad nature, CCI-LC classes were harmonised using their correspondence with IPCC land categories (UCL Geomatics, 2017). 
Table 3: Land cover classes present in the three original land cover maps, and the harmonised class they were assigned to.

\begin{tabular}{|c|c|c|c|}
\hline $\begin{array}{l}\text { Harmonised } \\
\text { class }\end{array}$ & $\mathbf{L C M}$ & CLC & CCI-LC \\
\hline Grassland & $\begin{array}{l}\text { Acid grassland } \\
\text { Calcareous } \\
\text { grassland } \\
\text { Improved grassland }\end{array}$ & $\begin{array}{l}\text { Natural grasslands } \\
\text { Pastures }\end{array}$ & $\begin{array}{l}\text { Grassland } \\
\text { Mosaic herbaceous cover }(>50 \%) / \\
\text { tree and shrub }(<50 \%)\end{array}$ \\
\hline $\begin{array}{l}\text { Arable and } \\
\text { horticulture }\end{array}$ & $\begin{array}{l}\text { Arable and } \\
\text { horticulture }\end{array}$ & $\begin{array}{l}\text { Non-irrigated arable } \\
\text { land }\end{array}$ & $\begin{array}{l}\text { Cropland, rainfed - } \\
\text { Herbaceous cover } \\
\text { Mosaic cropland }(>50 \%) / \text { natural } \\
\text { vegetation (tree, shrub, herbaceous } \\
\text { cover) }(<50 \%) \\
\text { Mosaic natural vegetation (tree, } \\
\text { shrub, herbaceous cover) }(>50 \%) / \\
\text { cropland }(<50 \%)\end{array}$ \\
\hline Bog & Bog & Peat bogs & $\begin{array}{l}\text { Shrub or herbaceous cover, flooded, } \\
\text { fresh/saline/brakish water }\end{array}$ \\
\hline Woodland & $\begin{array}{l}\text { Broadleaf } \\
\text { woodland } \\
\text { Coniferous } \\
\text { woodland }\end{array}$ & $\begin{array}{l}\text { Broad-leaved forest } \\
\text { Coniferous forest } \\
\text { Mixed forest } \\
\text { Transitional } \\
\text { woodland-shrub }\end{array}$ & $\begin{array}{l}\text { Tree cover, broadleaved, deciduous, } \\
\text { closed to open }(>15 \%) \\
\text { Tree cover, needleleaved, evergreen, } \\
\text { closed to open }(>15 \%) \\
\text { Mosaic tree and shrub }(>50 \%) / \\
\text { herbaceous cover }(<50 \%)\end{array}$ \\
\hline Freshwater & Freshwater & $\begin{array}{l}\text { No equivalent } \\
\text { mapped in the five } \\
\text { farm areas }\end{array}$ & $\begin{array}{l}\text { No equivalent mapped in the five } \\
\text { farm areas }\end{array}$ \\
\hline Heather & $\begin{array}{l}\text { Heather } \\
\text { Heather grassland }\end{array}$ & Moors and heathland & $\begin{array}{l}\text { No equivalent mapped in the five } \\
\text { farm areas }\end{array}$ \\
\hline Bare areas & Inland rock & $\begin{array}{l}\text { Mineral extraction } \\
\text { sites } \\
\text { Sparsely vegetated } \\
\text { areas }\end{array}$ & Bare areas \\
\hline $\begin{array}{l}\text { Built-up } \\
\text { areas }\end{array}$ & $\begin{array}{l}\text { Suburban } \\
\text { Urban }\end{array}$ & $\begin{array}{l}\text { Discontinuous urban } \\
\text { fabric } \\
\text { Sport and leisure } \\
\text { facilities }\end{array}$ & Urban areas \\
\hline
\end{tabular}




\subsection{Accuracy assessment}

An accuracy assessment of the three land cover maps was carried out for each of the five farm sites. Reference data pertaining to the eight harmonised land cover classes was collected by a single researcher through manual visual interpretation of high resolution aerial photography (Esri World Imagery layer, 2009-2016). The reference data were collected at point locations using a stratified random sampling approach. As the product with the highest spatial resolution, LCM was used to stratify the reference points according to land cover class. For each class, reference points were created at random locations within the boundaries of that class at each site, with the number of points being equal to one point per ten hectares of that class. A minimum spacing of $25 \mathrm{~m}$ was used, and a minimum of three points were sampled for each class, at each study site. Points that lay on the boundary between two land cover classes, or where the land cover could not be accurately distinguished were excluded (Table 4). Confusion matrices were then constructed using the reference data and three land cover maps at each site, and the overall accuracy (\%) and kappa coefficient was calculated.

Table 1: Number of reference points classified and excluded at each site.

\begin{tabular}{l|r|r}
\hline \multicolumn{1}{c|}{ Site } & $\begin{array}{c}\text { Reference points used for } \\
\text { validation }\end{array}$ & $\begin{array}{c}\text { Number of reference points } \\
\text { excluded }\end{array}$ \\
\hline Site 1 & 72 & 1 \\
Site 2 & 482 & 15 \\
Site 3 & 412 & 7 \\
Site 4 & 33 & 1 \\
Site 5 & 85 & 12
\end{tabular}

\subsection{Ecosystem service valuations}

Ecosystem service valuations (Table 5) were primarily calculated from UK natural capital ecosystem service accounts (Connors and Philips, 2017). These accounts present the total monetary value of ecosystem services provided by farmland (arable and horticultural land, improved grassland and rough grazing), freshwater (wetlands and open waters) and woodland (coniferous and deciduous) for the whole of the UK. The general methodologies used to obtain these valuations are outlined in Philips (2017), and vary depending on the ecosystem service and natural capital asset from which it originates. For example, for timber provision, the volume of removals is sourced from the Forestry Commission, and their value from the Forestry Commission Coniferous Standing Sales Price Index. For recreational visits to freshwaters, the number of visits and amount spent during trips were obtained from Natural England's Monitoring Engagement in the Natural Environment survey. Admission fees and travel expenditure are then used as an estimate of willingness to pay for access to the site through the travel cost method. The values of each service provided by an asset are then summed to obtain an overall valuation. For example, woodland is assigned a high valuation primarily due to the significant value of carbon sequestration and pollution removal.

For each land cover, we divided the total value of services provided by its total area in the UK to derive a per unit area value in the format $£ / h a / y r$. For some years valuations within the accounts were incomplete, with some services not being valued, and so here the most recent complete valuation was used. Values for heather and bog, or comparable land covers, were not available from Connors and Philips (2017), and so were sourced from the literature. Similar to the UK natural capital accounts, this study calculated first the physical (Remme et al., 2014) and then monetary (Remme et al., 2015) 
flows of services using various methods. Monetary valuations were then divided by the area of landcover to produce a per hectare valuation. Values for built-up and bare areas were assumed to be zero, although this is likely to be an underestimate.

The resulting valuations are therefore based on best available data but are limited by the broad nature of the classification systems used in the primary studies. For example, it is recognised that service provision from grassland and arable land will differ. However, at this time they are treated as a single unit within the UK natural capital ecosystem accounts and disaggregation is not currently possible. Similarly, not all ecosystems are valued, and different services are valued for the different land covers. Other factors that will affect ecosystem service flow such as the condition, configuration and location of natural capital assets are also not accounted for here, but are identified as an important topic for future research (section 4.1). 
Table 5: Details of ecosystem service valuations used, showing how the original valuations map onto the harmonised land cover classes used in this study.

\begin{tabular}{|c|c|c|c|c|c|}
\hline $\begin{array}{c}\text { Valuation } \\
\text { class }\end{array}$ & $\begin{array}{c}\text { Value } \\
(\mathfrak{f} / \mathbf{h a} / \mathbf{y r})\end{array}$ & Source & Services Valued & Notes & Harmonised Class \\
\hline Farmland & 105 & $\begin{array}{l}\text { Connors and } \\
\text { Philips (2017) }\end{array}$ & $\begin{array}{l}\text { Crops and grazed biomass } \\
\text { Water abstraction } \\
\text { Pollution removed } \\
\text { Time spent at habitat } \\
\text { Education visits }\end{array}$ & $\begin{array}{l}\text { For year 2014. Includes arable and } \\
\text { horticulture, improved grassland and rough } \\
\text { grazing }\end{array}$ & $\begin{array}{l}\text { Arable and } \\
\text { horticulture } \\
\text { Grassland }\end{array}$ \\
\hline Freshwater & 569 & $\begin{array}{l}\text { Connors and } \\
\text { Philips (2017) }\end{array}$ & $\begin{array}{l}\text { Water abstraction } \\
\text { Peat extraction } \\
\text { Fish capture } \\
\text { Pollution removed } \\
\text { Time spent at habitat }\end{array}$ & For year 2013 & Freshwater \\
\hline Woodland & 738 & $\begin{array}{l}\text { Connors and } \\
\text { Philips (2017) }\end{array}$ & $\begin{array}{l}\text { Total timber removals } \\
\text { Carbon sequestration } \\
\text { Pollution removal } \\
\text { Time spent at habitat }\end{array}$ & For year 2015 & Woodland \\
\hline Heath & 384 & $\begin{array}{l}\text { Remme } \text { et al. } \\
\text { (2015), Remme } \\
\text { et al. (2014) }\end{array}$ & $\begin{array}{l}\text { Hunting } \\
\text { Drinking water extraction } \\
\text { Air quality regulation } \\
\text { Carbon sequestration } \\
\text { Nature tourism }\end{array}$ & $\begin{array}{l}\text { Average value used. Converted from } \\
€ 426 / \mathrm{ha} / \mathrm{yr}\end{array}$ & Heather \\
\hline Peatland & 412 & $\begin{array}{l}\text { Remme } \text { et al. } \\
\text { (2015), Remme } \\
\text { et al. (2014) }\end{array}$ & $\begin{array}{l}\text { Hunting } \\
\text { Air quality regulation } \\
\text { Carbon sequestration } \\
\text { Nature tourism }\end{array}$ & $\begin{array}{l}\text { Average value used. Converted from } \\
€ 457 / \mathrm{ha} / \mathrm{yr}\end{array}$ & Bog \\
\hline Built-up areas & 0 & Assumed value & $\mathrm{n} / \mathrm{a}$ & $\mathrm{n} / \mathrm{a}$ & Built-up areas \\
\hline Bare areas & 0 & Assumed value & $\mathrm{n} / \mathrm{a}$ & $\mathrm{n} / \mathrm{a}$ & Bare areas \\
\hline
\end{tabular}




\subsection{Valuation process}

The total extent of each land cover type as recorded by the three land cover datasets was calculated for each farm. These were then multiplied by the value per unit area for each land cover type to obtain a total annual monetary value of ecosystem services for each farm. The total value was then divided by the total area of each farm to calculate an average value of ecosystem services per hectare, for comparison with current government subsidy values which are expressed on a per hectare basis and for comparison with valuations performed in previous research.

\section{Results}

\subsection{Comparison of land cover datasets}

\subsubsection{Accuracy}

The accuracy assessment indicates that LCM is the most accurate of the three products assessed (Table 6), with the highest overall accuracy, $19-35 \%$ greater than CCI-LC or CLC at all locations barring Site 4 (the small dairy farm), and the highest kappa coefficient at all sites. The overall accuracy for LCM ranges from $78 \%$ at Site 2, to $89 \%$ at Site 5. CLC and CCI-LC display similar overall accuracies, with at most a $3.6 \%$ difference between them (Site 3 ).

Table 6: Overall accuracy and kappa coefficient for the three land cover maps at each site.

\begin{tabular}{l|rr|rr|rr}
\hline \multicolumn{1}{c|}{ Site } & \multicolumn{2}{|c|}{ LCM } & \multicolumn{2}{c|}{ CLC } & \multicolumn{2}{c}{ CCI-LC } \\
& $\begin{array}{l}\text { Accuracy } \\
(\%)\end{array}$ & Kappa & $\begin{array}{c}\text { Accuracy } \\
(\%)\end{array}$ & Kappa & Accuracy & Kappa \\
& & & & & \\
\hline Site 1 & 86 & 0.80 & 53 & 0.23 & 51 & 0.20 \\
Site 2 & 78 & 0.59 & 58 & 0.34 & 59 & 0.12 \\
Site 3 & 83 & 0.67 & 67 & 0.36 & 63 & 0.12 \\
Site 4 & 85 & 0.49 & 88 & 0.40 & 88 & 0 \\
Site 5 & 89 & 0.84 & 69 & 0.53 & 71 & 0.52
\end{tabular}

\subsubsection{Spatial and thematic resolution}

Visual inspection of the harmonised maps produced for each site indicates that while all datasets show broadly similar patterns of land cover, there are significant differences. LCM, having the highest spatial resolution, records smaller patches of land cover. This is especially apparent at Site 3 (Figure 2) where LCM records many small patches of trees scattered across the landscape, while CLC shows only the larger patches at the southern and northern ends, and CCI-LC only woodland to the north. Here, nearly half of the woodland recorded by LCM is present in parcels below 25 ha (the minimum mappable unit of CLC), and 19\% in parcels below $100 \mathrm{~m}$ (the minimum mappable width of CLC) (Table 7). 
Table 7: The proportion of woodland recorded by LCM present in parcels below 25 ha in area, and below $100 \mathrm{~m}$ in width, the minimum mappable unit and width for CLC, respectively.

\begin{tabular}{l|r|r}
\hline \multicolumn{1}{c|}{ Site } & \% woodland below 25 ha & \% woodland below 100 m \\
\hline Site 1 & 14 & 19 \\
Site 2 & 12 & 6 \\
Site 3 & 43 & 19 \\
Site 4 & 8 & 85 \\
Site 5 & 9 & 5
\end{tabular}

LCM

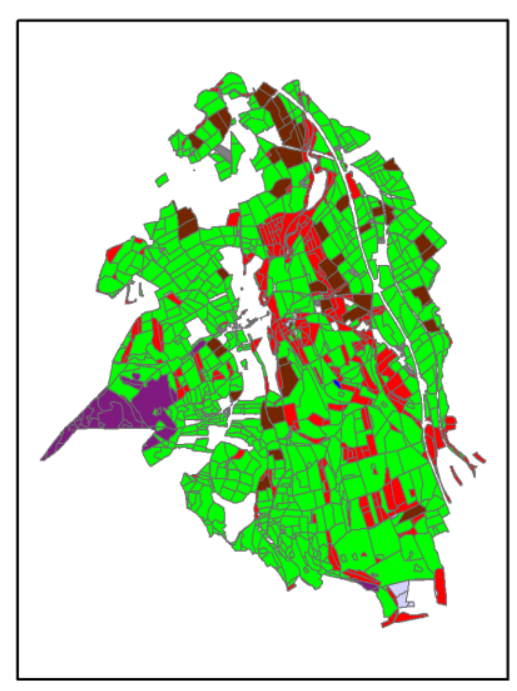

5 Kilometres
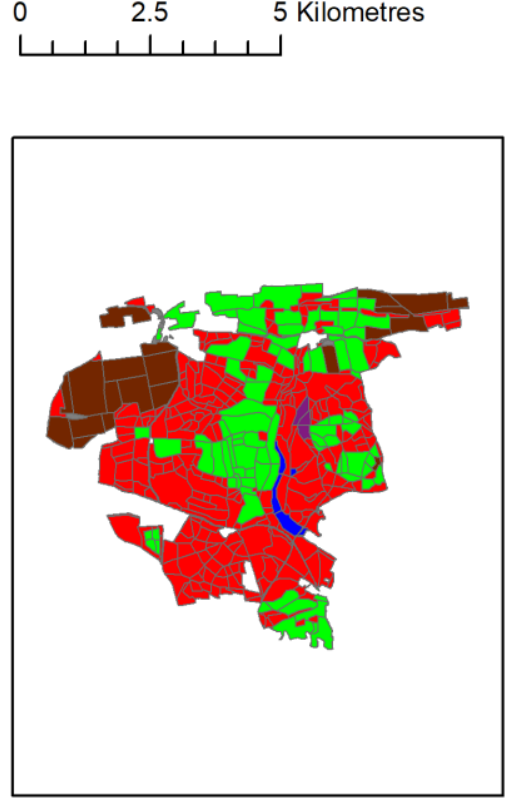

$\begin{array}{lll}0 & 1 & \text { Kilometres }\end{array}$

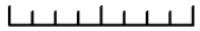

CLC
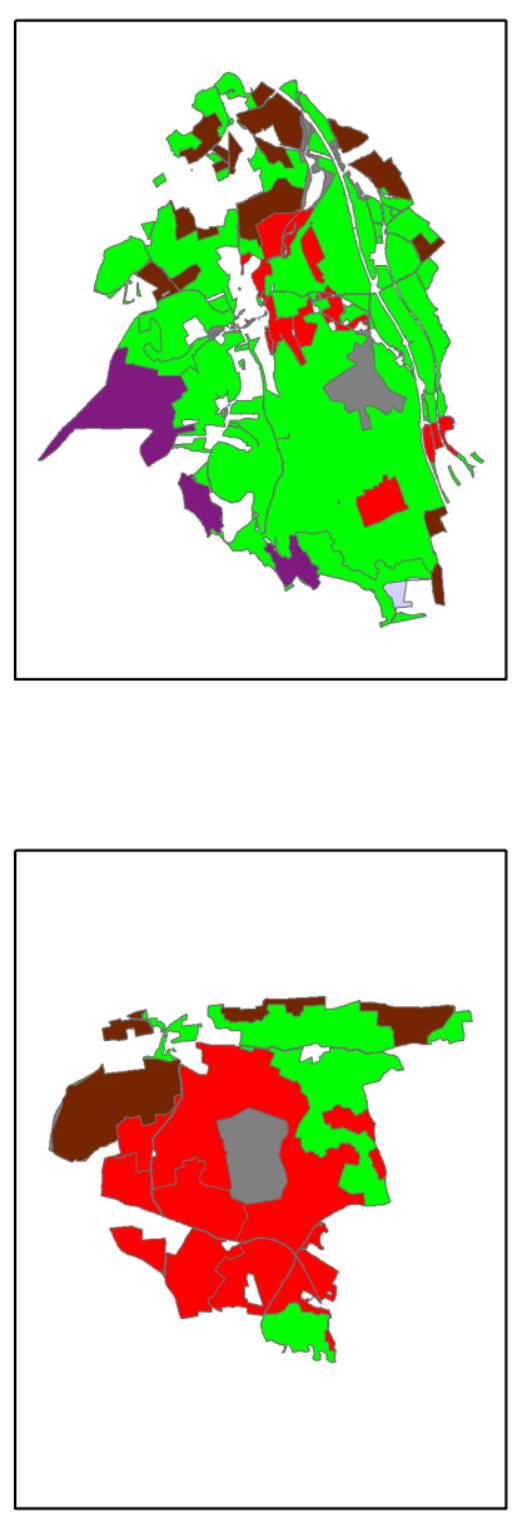

Arable and horticulture Bare areas
Built-up areas Freshwater
CCI-LC
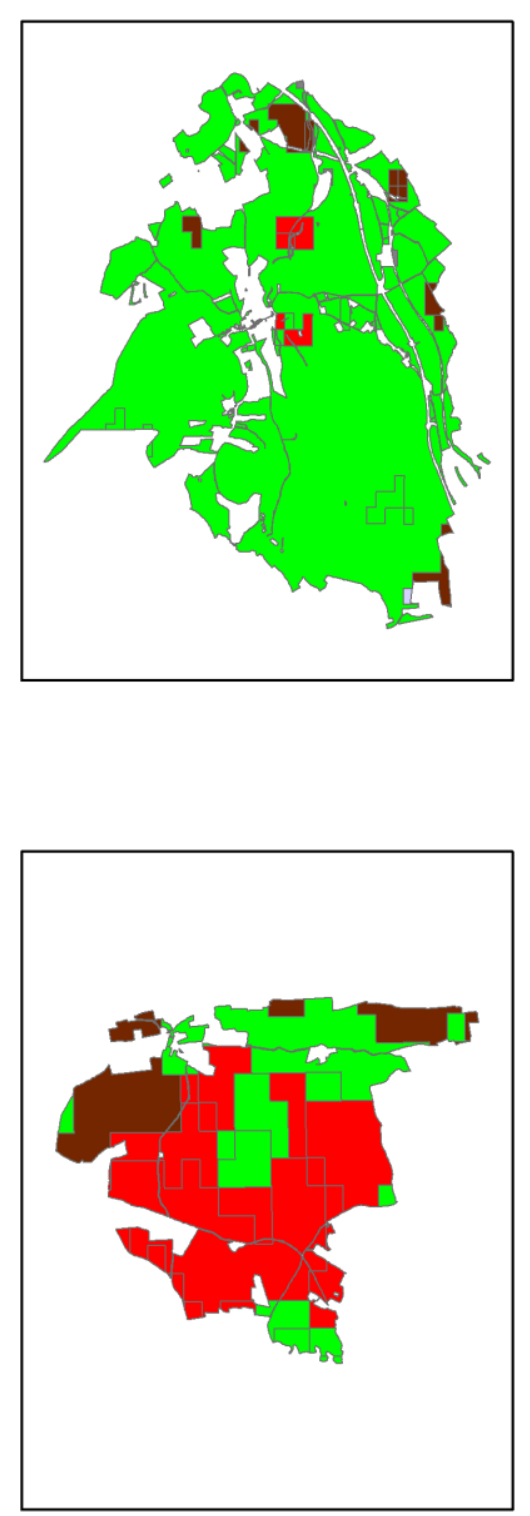

Grassland Woodland Heather

Figure 2: Land cover maps, using the harmonised classification scheme, for Site 3 (top) and Site 5 (bottom). 
When the land cover maps are harmonised according to Table 3, LCM records the most classes and CCI-LC the least for all sites (Table 8). This is due to both the spatial and thematic characteristics of the products used. The high spatial resolution of LCM makes it possible to record smaller features such as the river at Site 5 (Figure 2) and buildings at Site 1 and Site 2, which are not included in the other datasets. CCI-LC does not include a class for heather or comparable land covers, instead including it within broad shrub and herbaceous cover categories, which when harmonised are classed as grassland and bog.

Table 8: Number of unique land cover classes recorded at each site by each dataset, using the harmonised classification system described in Table 3.

\begin{tabular}{|c|c|c|c|}
\hline Site & LCM & CLC & CCI-LC \\
\hline Site 1 & 6 & 3 & 3 \\
\hline Site 2 & 6 & 5 & 4 \\
\hline Site 3 & 7 & 6 & 5 \\
\hline Site 4 & 3 & 2 & 1 \\
\hline Site 5 & 6 & 5 & 3 \\
\hline
\end{tabular}

The land cover classes used by LCM, based on UK Biodiversity Action Plan Broad Habitats (Jackson, 2000), were easily matched with ecosystem service valuations used here (Connors and Philips, 2017; Remme et al., 2015). However, the original CLC classification system includes both land use and land cover classes. This can be seen at Site 3 and Site 5 (Figure 2), where large areas of grassland are classed by CLC as sport and leisure facilities. As this category can include both green space and buildings, it was assigned to built-up areas in our harmonised classification scheme. However, in reality, the area recorded is simply fields used for recreational activities. Similarly, the original CCILC classification scheme uses several broad mosaic classes, such as mosaic natural vegetation (tree, shrub, herbaceous cover) ( $>50 \%) /$ cropland $(<50 \%)$, aggregating together features that have significantly different ecosystem service values.

\subsubsection{Monetary ecosystem service accounts}

Total ecosystem service valuations range from $£ 33,110$ per annum at Site 4 (using CLC and CCI-LC) to $£ 1,264,299$ per annum at Site 2 (using CLC) (Table 9). Figure 3 shows the distribution of ecosystem service values from each land cover class at the five sites. The average ecosystem service value per hectare ranges from $£ 105 / \mathrm{ha} / \mathrm{yr}$ at Site 4 (using CLC and CCI-LC), to $£ 456 / \mathrm{ha} / \mathrm{yr}$ at Site 5 (using LCM) (Table 10). 
Table 9: Total annual ecosystem service valuations for each site, as derived from the three different harmonised land cover maps.

\begin{tabular}{l|r|r|r}
\hline & \multicolumn{4}{c}{ Total ecosystem service valuation (£/yr) } \\
\cline { 2 - 5 } & \multicolumn{2}{|c}{ CCM } & \multicolumn{2}{c}{ CCI-LC } \\
\hline Site 1 & 170,269 & 119,605 & 98,623 \\
Site 2 & $1,254,608$ & $1,264,299$ & 792,526 \\
Site 3 & 870,135 & 694,129 & 478,186 \\
Site 4 & 35,399 & 33,110 & 33,110 \\
Site 5 & 410,721 & 387,564 & 404,215
\end{tabular}

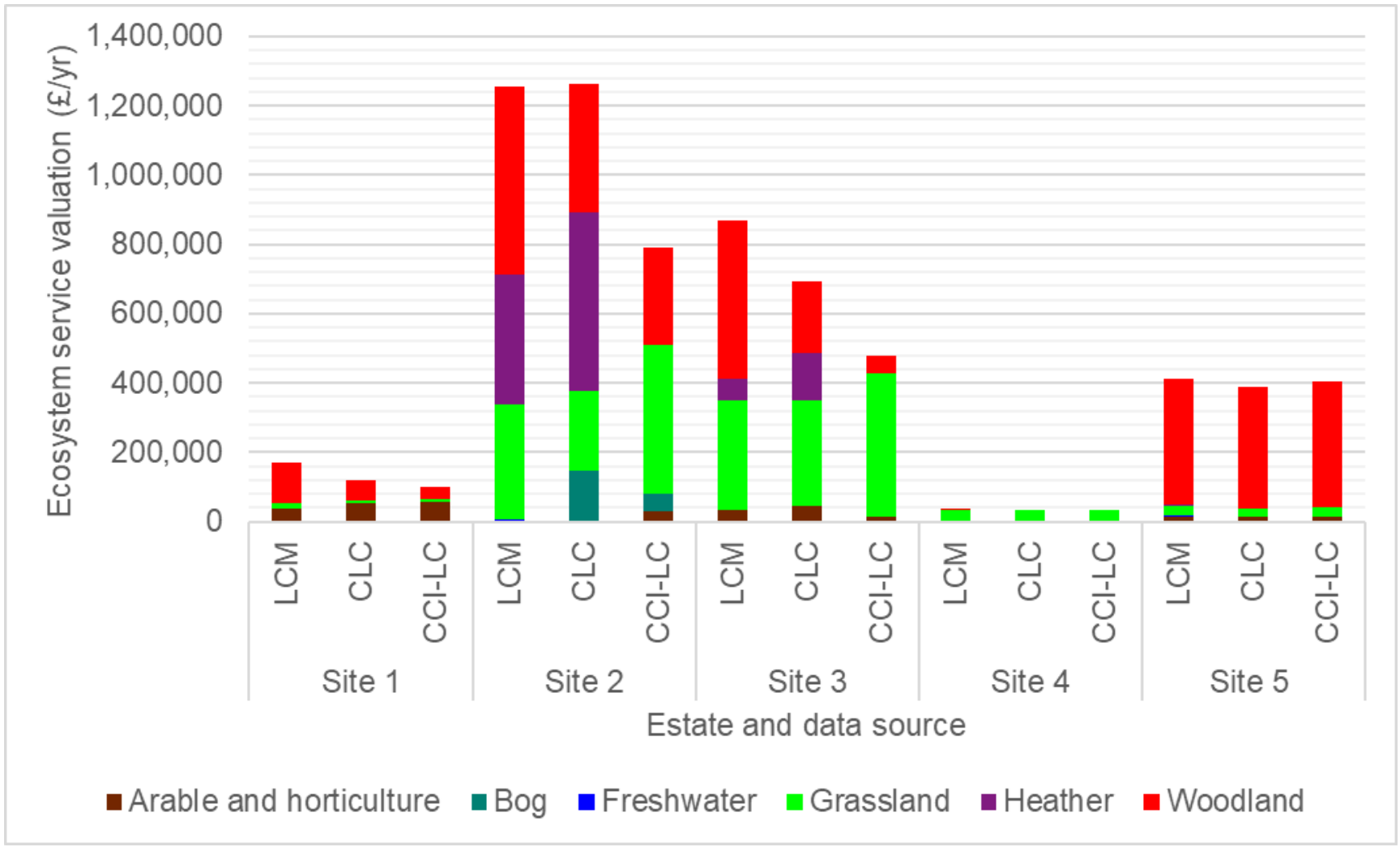

Figure 3: Ecosystem service valuations by land cover class for the five sites, based on the three different harmonised land cover maps.

Table 10: Average annual ecosystem service value per hectare for each site, as derived from the three different land cover maps.

\begin{tabular}{l|r|r|r}
\hline & \multicolumn{4}{c}{ Average ecosystem service valuation (£/ha/yr) } \\
\cline { 2 - 5 } & LCM & \multicolumn{3}{|c}{ CLC } & 183 & 151 \\
\hline Site 1 & 261 & 258 & 162 \\
Site 2 & 256 & 167 & 115 \\
Site 3 & 210 & 105 & 105 \\
Site 4 & 112 & 431 & 449 \\
Site 5 & 456 & &
\end{tabular}


It is clear that the varying spatial and thematic characteristics of the land cover data used has a significant impact on final monetary valuations. Using LCM as the input spatial data results in the highest valuations for all sites, bar Site 2, where CLC results in a slightly higher valuation. Conversely, CCI-LC leads to the lowest valuations at all sites except Site 5, where CLC is marginally lower.

LCM records the most woodland at all sites, in part due to its ability to record small and narrow parcels of trees. As woodland has the highest ecosystem service value ( $£ 738 / \mathrm{ha} / \mathrm{yr})$, this results in a higher overall valuation. The ability of LCM to detect a wider range of land cover types and smaller features has a minor impact. For example, the presence of freshwater accounts for at most $1.3 \%$ of a valuation (Site 5). Rather, at most sites valuations are primarily dominated by farmland (arable and grassland), which has a low value (£105/ha/yr) but is present in large areas, and woodland, which has the highest value and is present in moderate amounts.

The characteristics of the sites themselves also influence valuations and the suitability of different datasets for producing them. The consistency of valuations produced using different land cover data vary considerably between sites. At certain farms, such as Site 3, the landscape is highly fragmented, with small patches of land cover, especially trees, scattered throughout the site. Here, annual valuations range from $£ 478,186$ using CCI-LC to $£ 870,135$ using LCM, a difference of $58 \%$, with LCM recording 620 ha of woodland, and CCI-LC just 69 ha. Conversely, at sites such as Site 5, the landscape, and especially areas of woodland, are more continuous. Here valuations are the most homogenous, ranging from $£ 387,564$ using CLC to $£ 410,721$ based on LCM, a difference of just 6\%. This indicates that at certain sites with large continuous areas of land cover, coarser resolution datasets such as CLC and CCI-LC may be suitable for producing valuations, while at others the ability to distinguish small patches of land cover, and therefore a high resolution product, is required.

While most sites examined in this study are dominated by woodland and farmland, at Site 2 heather also makes a significant contribution to valuations. The upland heather moorland environment of this site results in perhaps the most uncertain of valuations produced. Here, $17 \%$ of the land area is classified differently in each dataset. LCM has its lowest accuracy of all sites, while for CCI and CORINE it is their second lowest behind Site 1. This may be due to the difficulties involved in classifying spectrally similar land covers, or differences in their exact definition. For example, while LCM requires an area to have a layer of peat $50 \mathrm{~cm}$ or higher to be classified as bog (Centre for Ecology \& Hydrology, 2017), for CLC the requirement is $30 \mathrm{~cm}$ (Kosztra et al., 2019). The landscape here is also very much a mosaic, with it being difficult to determine when one land cover ends, and another begins.

\section{Discussion}

The use of secondary data within a land cover and benefit transfer methodology allowed for farm scale valuations to be produced rapidly and at little cost, with the most time-consuming aspect being the identification of ecosystem service valuations per unit area for the different land cover types.

The average ecosystem service value per hectare ranges from $£ 105 / \mathrm{ha} / \mathrm{yr}$ to $£ 456 / \mathrm{ha} / \mathrm{yr}$, which is comparable to current agricultural subsidies in the UK provided through the Basic Payments Scheme. However, these payments, which range from $£ 63 / \mathrm{ha} / \mathrm{yr}$ to $£ 232 / \mathrm{ha} / \mathrm{yr}$ in England (Rural Payments Agency, 2018b) and £12/ha/yr to £218/ha/yr in Scotland (Rural Payments \& Services, 2016), are provided only for grassland (including heather suitable for grazing) and arable land (Rural Payments Agency, 2018; Rural Payments \& Services, 2017), which were found to have the lowest ecosystem service valuations. Features such as woodland, which have the highest valuations, are excluded. Additional funding can be sought through schemes such as the Rural Development Program for 
England which provides payments not only for agricultural land, but also includes multi-year grants for the creation and management of woodland (Rural Payments Agency et al., 2019). It is also important to note that the valuations produced in this study should be interpreted as partial or minimal as a number of ecosystem services, such as pollination, are not included (Connors and Philips, 2017). This complexity makes meaningful comparison between the measured ecosystem service valuation for a site, the true value of services provided, and the total amount of subsidies and funding available difficult.

In a test study, eftec (2018) found that without agricultural subsidies, both an environmentally focused organic estate and a more typical intensive farm would make a loss financially. However, while the environmentally focused site produced net benefits from natural capital such as soil carbon sequestration, the more typical site led to a degradation of public goods. Introducing a natural capital approach to agricultural policy development would allow for the impact of farming practices on the environment, both positive and negative, to be demonstrated, and ensure that funding supports both beneficial farming practices, as well as food production.

It is difficult to compare valuations presented here with past studies using the land cover and benefit transfer approach, as these have been carried out in significantly different environments and at different scales. Sutton and Costanza (2002) determined a total terrestrial ecosystem service value of $\$ 49$ billion for the whole of the UK, equal to an average of $£ 1593 / \mathrm{ha} / \mathrm{yr}^{1}$, which is significantly higher than estimates produced for the agricultural sites in this study. This may in part be due to higher valuations for certain land cover classes, as well as differences in the distribution of land cover in agricultural areas versus the country as a whole. Troy and Wilson (2006) derived valuations for a number of sites of varying spatial scales in the USA. Again, ecosystem service valuations are generally higher than those used here, being inflated by highly valued coastal and wetland classes. For example, 'Freshwater wetland' at Maury Island is valued at $£ 57,502 / \mathrm{ha} / \mathrm{yr}^{1}$, and 'Fresh water bodies / coastal embayments’ at Massachusetts £30,165/ha/yr ${ }^{1}$. This suggests that valuations in the present study are lower than those seen in previous studies due to the inland locations of the sites used and lack of inland water bodies. Kreuter et al. (2001) calculated an average value of $£ 118 / \mathrm{ha}^{\mathrm{yr}} \mathrm{y}^{1}$ to $£ 126 / \mathrm{ha} / \mathrm{yr}^{1}$ for a 141,67 ha area of San Antonio, Texas, using the same ecosystem service values per land cover type as Sutton and Costanza (2002). This is significantly lower than valuations in other studies, and comparable to those generated by the present study. This may be due to the land cover classes recorded in the study area: 'Rangeland', 'Woodland', 'Bare soil', 'Residential' and 'Commercial and Transportation', with no highly valued coastal or wetland classes, which are comparable to the land covers at the five sites in this study. These studies also value different services. For example, Sutton and Costanza (2002) and Kreuter et al. (2001) include valuations for a number of services not considered here (Table 5) including biological control, genetic resources and soil formation. Troy and Wilson (2006) similarly account for soil retention and formation. Conversely, educational visits to farmland are accounted for in our study, but not in these previous studies.

\subsection{Uncertainties and future work}

In the land cover and benefit transfer approach, land cover is used as a proxy for ecosystem service supply. However, there are uncertainties associated with this. Eigenbrod et al. (2010) compared land cover-based proxies to primary data, finding that while proxies may be suitable for identifying broadscale trends in ecosystem services, there was a poor fit of proxies to the primary data. Nevertheless, as highlighted earlier, it is impractical and financially prohibitive to collect primary field survey data on ecosystem services across the broad spatial scales covered in this study. The spatially continuous nature of land cover maps offers a more comprehensive method for quantifying ecosystem services.

\footnotetext{
${ }^{1}$ Using an exchange rate of $1 \mathrm{USD}=0.79 \mathrm{GBP}$, obtained 20 June 2019
} 
As acknowledged in section 2.5, the valuation categories used here are broad, aggregating together for example farmland and grassland, limiting the accuracy of valuations produced. It can be expected that in time, as the number of primary valuations increases, the use of more fine grained classification schemes will become more viable. Due to the simple nature of the valuation approach used here, it would be straightforward for valuations per unit area to be updated to reflect improvements in knowledge of ecosystem service provision.

In this work we use a simple benefit transfer technique, with unadjusted unit values obtained from existing studies. However, more sophisticated approaches exist, such as value function transfer which predicts ecosystem service values as functions of the characteristics of the assets, the beneficiaries, and the context within which they will be provided (Ready and Navrud, 2005; Brouwer, 2000).

Schägner et al. (2013) reviewed methodologies for mapping ecosystem service values. By using a single value for each type of asset, there is an assumption that ecosystem service supply and value is uniform across a given land cover. However, this is a gross simplification. Other techniques include the use of adjusted unit values, value functions, and validated and non-validated models. Through the use of these more sophisticated techniques, a range of attributes can and should be considered when estimating the value of ecosystem services provided. In the UK natural capital accounts methodology (Philips, 2017), natural assets are identified as stocks, which give rise to flows of services. Three main characteristics are described which can influence the capacity of these stocks of assets to deliver ecosystem services: extent, condition and spatial configuration. Included in measures of condition is proximity to areas of population. We suggest that this could be considered as part of a wider assessment of the location of the asset, that is, its position in relation to other assets. Based on this, we propose a four step framework for the assessment of natural capital stocks in order to accurately assess flows of services in physical and then monetary terms (Figure 4Error! Reference source not found.).

\section{Stocks}

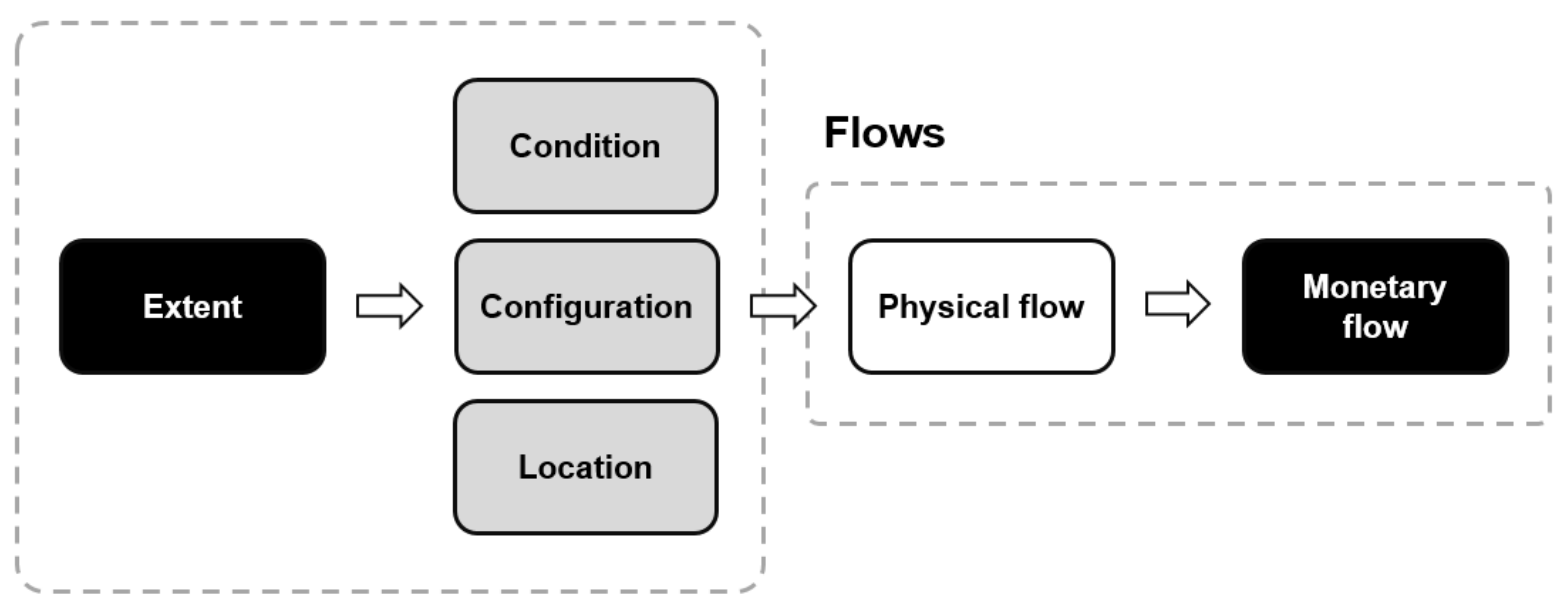

Figure 4: The proposed sequence for natural capital valuations, adapted from Philips (2017).

This work demonstrates that farm scale monetary valuations produced using a land cover and benefit transfer approach can be highly sensitive to the characteristics of the land cover data used, due to variations in the extent of different land covers recorded (black boxes, Figure 4). Uncertainty is therefore introduced immediately in the first step of this framework. Future work should consider the condition, configuration and location of stocks (grey boxes, Figure 4) to more accurately value flows 
of services in physical and monetary terms, and assess the uncertainties involved in their measurement.

Condition, otherwise referred to as quality, includes the attributes of an asset, such as water quality and soil carbon content. Here it is assumed that all assets are functioning equally and provide the same services, using a simple single value per unit area approach. For valuations derived from the UK natural capital accounts, benefits from one scale (national) are applied to a very different scale (individual farms), meaning assets are given a value averaged across all assets across the UK. For valuations derived from the literature, assets are assumed to be functioning the same as those in the study area that values were derived from. These valuations will include services that are not applicable to all sites. As an example, valuations for farmland include values for educational visits and recreational time spent at the habitat, however not all sites used in this study allow these. Troy and Wilson (2006) give the example of the recreational value of coniferous forest, which may yield different results if the forest is on public or private land due to differences in access. Where services are provided by an asset, the magnitude of this provision will be affected by a range of factors. A simple example would be how the value of woodland as a wildlife habitat changes depending on its age, tree species composition and the health of the trees. These ecosystem service indicators are likely to be complex. In this example, different wildlife will prefer different conditions, and different species of wildlife could be considered more or less valuable in different locations. Management practices, such as the distinction between organic and conventional farming, will also impact the condition of assets. Studies have shown that organic farming has a positive effect on biodiversity when compared with conventional techniques for example (Bengtsson et al., 2005; Winqvist et al., 2011; Tuck et al., 2014), and on the provision of ecosystem services including soil carbon storage (Drinkwater et al., 1995) and in certain landscapes biological control (Winqvist et al., 2011). Farm management practices may also result in negative externalities, or ecosystem disservices, such as eutrophication caused by fertilizer usage. These are not considered in this work, which focuses on the valuation of ecosystem services, but would need to form part of a more comprehensive assessment of the environmental impacts of agriculture.

The configuration of an asset will also have an impact, with factors such as fragmentation and connectivity being known to affect the value of a habitat for biodiversity. Similarly, the recreational value of a tree will vary depending on whether it stands alone or is part of a wider woodland. Measures of configuration are not currently included in the UK natural capital accounts as they are noted to be challenging to compile (Philips, 2017). While configuration can be considered as the position of an asset in relation to itself, location refers to the position of an asset in relation to other assets or features. Dales and Lusardi (2014) note how knowledge of the locations of an asset and beneficiaries of ecosystem services would be advantageous. For example, a habitat supporting pollinators may be more valuable when located near to certain agricultural crops. Similarly, a woodland may have more value for recreation when located near areas of population (Philips, 2017).

Not all ecosystem services have been accounted for in this study, and it is unlikely that we will ever be able to accurately quantify and appreciate the full extent of all the benefits provided by nature. Any valuations produced should therefore be seen as partial, or a lower bound, only. Some natural capital assets and the services they provide are also not accounted for due to the spatial and thematic resolution of the data used. The urban classes in both LCM and CLC include green space such as gardens and parks, as well as artificial surfaces. As the ecosystem service value of urban areas was assumed to be zero, the value of urban green space has not been accounted for, although it is known to be significant (Anderson, 2018; Willis and Petrokofsky, 2017). This being said, as the farms examined in this study are predominantly rural and agricultural in nature with limited (if any) urban areas, the impact of this would be expected to be small. 
Augmenting the land cover maps used in this study with additional more accurate or detailed layers would improve the accuracy of valuations. Of the three datasets tested, LCM was found to be the most accurate, with an overall accuracy ranging from $78 \%$ to $89 \%$, indicating there is room for improvement at all sites. Woodland, as a significant contributor to valuations at most sites, and land covers such as bog and heather which were classified poorly in existing datasets could be valuable targets for future work. For example, the CEH Woody Linear Features Framework (Scholefield et al., 2016) could be used to include hedges and narrow lines of trees, which are not included in any of the land cover datasets used in this study. Alternatively, land cover data could be optimised before use. Dales and Lusardi (2014) suggest that local practitioners could clean the data before analysis is carried out. Other data sources, such as aerial photography or topographic mapping could also be used to check and update land cover data, assuming data were available for the appropriate date. Both options however would require additional time and effort to be devoted to the creation of valuations. Finally, as well as improving the accuracy of surface land cover data, valuations could also be improved by accounting for features in the subsurface. As an example, only surface water, and not ground water is valued here, but incorporating this component would require the use of additional data.

\section{Conclusion}

This work demonstrates a land cover and benefit transfer-based approach to natural capital and ecosystem service valuation on individual UK farms. The suitability of three widely available land cover products was assessed. It was found that the varying spatial and thematic characteristics of these products can have a significant impact on final valuations. LCM was found to be the most accurate at most sites, and its use as the input spatial data also results in the highest valuations at the majority of farms. This is partly due to the ability of LCM to detect small patches of land cover, especially trees, scattered through the landscape, inflating valuations. The impact of this is greatest at sites where the landscape is fragmented, and less where it is more homogenous. The presence of bog and heather also make a notable contribution to valuations at some sites, especially the upland hill farm studied. These land covers appear to be mapped less accurately, with disagreement between the datasets examined. As well as spatial resolution, thematic resolution is also important, as it is difficult to assign the land use classes of CLC and mosaic classes of CCI-LC to suitable values from primary studies.

Using a land cover and benefit-transfer approach allows ecosystem service valuations to be produced rapidly, and at little or in some cases no cost. However, significant uncertainties are acknowledged, especially regarding the benefit transfer process. We describe a framework for future work that also accounts for the condition, configuration and location of natural capital assets to improve the accuracy of valuations produced, while the integration of additional, more accurate and detailed land cover data has the potential to reduce errors associated with the extent of assets.

\section{Acknowledgements}

The authors would like to thank the owners and managers of the sites studied for their time and assistance. We would also like to thank the contributions of two anonymous reviewers, who's input greatly improved the focus and clarity of this manuscript. This project is supported through the Centre for Global Eco-Innovation, part funded by the European Regional Development Fund. 


\section{References}

Anderson, H., 2018. UK natural capital: ecosystem accounts for urban areas. [Accessed 18 October 2019]. Available at:

https://www.ons.gov.uk/economy/environmentalaccounts/bulletins/uknaturalcapital/ecosystemaccoun tsforurbanareas

Bengtsson, J., Ahnström, J., Weibull, A. C., 2005. The effects of organic agriculture on biodiversity and abundance: A meta-analysis. Journal of Applied Ecology 42(2), 261-269.

https://doi.org/10.1111/j.1365-2664.2005.01005.x

Brenner, J., Jiménez, J. A., Sardá, R., Garola, A., 2010. An assessment of the non-market value of the ecosystem services provided by the Catalan coastal zone, Spain. Ocean \& Coastal Management 53, 27-38. https://doi.org/10.1016/j.ocecoaman.2009.10.008

Brouwer, R., 2000. Environmental value transfer: state of the art and future prospects. Ecological Economics 32, 37-152. https://doi.org/10.1016/S0921-8009(99)00070-1

Burkhard, B., Kroll, F., Müller, F., Windhorst, W., 2009. Landscapes' Capacities to Provide Ecosystem Services - A Concept for Land-Cover Based Assessments. Landscapes Online 15, 1-22. 10.3097/LO.200915

Burkhard, B., Maes, J., 2017. Introduction. In: Burkhard, B., Maes, J. (Eds.), Mapping Ecosystem Services. Pensoft Publishers, Sofia, p. 23.

Burkhard, B., Müller, A., Müller, F., Grescho, V., Anh, Q., Arida, G., Bustamante, J. V., Van Chien, H., Heong, K. L., Escalada, M., Marquez, L., Thanh Truong, D., Villareal, S., Settele, J., 2015. Land cover-based ecosystem service assessment of irrigated rice cropping systems in southeast Asia-An explorative study. Ecosystem Services 14, 76-87. https://doi.org/10.1016/j.ecoser.2015.05.005

Centre for Ecology \& Hydrology, 2017. Land Cover Map 2015 Dataset documentation Version 1.2. [Accessed 18 October 2019]. Available at: https://www.ceh.ac.uk/sites/default/files/LCM2015_Dataset_Documentation_22May2017.pdf

Committee on Climate Change, 2018. Land use: Reducing emissions and preparing for climate change 100. [Accessed 18 October 2019]. Available at: https://www.theccc.org.uk/wpcontent/uploads/2018/11/Land-use-Reducing-emissions-and-preparing-for-climate-change-CCC2018.pdf

Connors, E., Philips, J., 2017. UK natural capital: ecosystem accounts for freshwater, farmland and woodland. [Accessed 18 October 2019]. Available at:

https://www.ons.gov.uk/economy/environmentalaccounts/bulletins/uknaturalcapital/landandhabitatec osystemaccounts

Copernicus Programme, 2019. CORINE Land Cover. [Accessed 18 October 2019]. Available at: https://land.copernicus.eu/pan-european/corine-land-cover

Costanza, R., D’Arge, R., de Groot, R., Farber, S., Grasso, M., Hannon, B., Limburg, K., Naeem, S., O’Neill, R. V., Paruelo, J., Raskin, R.G., Sutton, P., van den Belt, M., 1997. The value of the world's ecosystem services and natural capital. Nature 387, 253-260. https://doi.org/10.1038/387253a0 
Dales, N., Brown, N., Lusardi, J., 2014. Assessing the potential for mapping ecosystem services in England based on existing habitats. [Accessed 18 October 2019]. Available at: http://publications.naturalengland.org.uk/publication/5280919459987456

Defra, 2018a. A Green Future: Our 25 Year Plan to Improve the Environment. [Accessed 17 October 2019]. Available at:

https://assets.publishing.service.gov.uk/government/uploads/system/uploads/attachment_data/file/693 158/25-year-environment-plan.pdf

Defra, 2018b. Health and Harmony: the future for food, farming and the environment in a Green Brexit. [Accessed 18 October 2019]. Available at:

https://assets.publishing.service.gov.uk/government/uploads/system/uploads/attachment_data/file/684 003/future-farming-environment-consult-document.pdf

Drinkwater, L. E., Letourneau, D. K., Workneh, F., van Bruggen, A. H. C., Shennan, C., 1995. Fundamental Differences Between Conventional and Organic Tomato Agroecosystems in California. Ecological Applications 5(4), 1098-1112. 10.2307/2269357

eftec, 2018. Cholderton Estate Natural Capital Account: An Illustration of How Good Farming Pays.

Eigenbrod, F., Armsworth, P. R., Anderson, B. J., Heinemeyer, A., Gillings, S., Roy, D. B., Thomas, C. D., Gaston, K. J., 2010. The impact of proxy-based methods on mapping the distribution of ecosystem services. Journal of Applied Ecology 47(2), 377-385. https://doi.org/10.1111/j.13652664.2010.01777.x

European Commission, 2011. Our life insurance, our natural capital: an EU biodiversity strategy to 2020. [Accessed 18 October 2019]. Available at: https://eur-lex.europa.eu/legalcontent/EN/TXT/PDF/?uri=CELEX:52011DC0244\&from=EN

European Court of Auditors, 2017. Special Report n²1/2017: Greening: a more complex income support scheme, not yet environmentally effective. [Accessed 20 December 2019]. Available at: https://www.eca.europa.eu/Lists/ECADocuments/SR17_21/SR_GREENING_EN.pdf

Eurostat, 2018. Agriculture, forestry and fishery statistics 2018 edition. [Accessed 28 October 2019]. Available at: https://ec.europa.eu/eurostat/documents/3217494/9455154/KS-FK-18-001-ENN.pdf/a9ddd7db-c40c-48c9-8ed5-a8a90f4faa3f

Hodge, I., 2017. Towards a British Ecosystem Services Policy. 90th Annual Conference of the Agricultural Economics Society. Royal Dublin Society. 24-26 April 2017. 1-16. [Accessed 18 October 2019]. Available at: https://ageconsearch.umn.edu/record/258640/files/Ian\%20_Hodge_Hodge\%20Towards\%20a\%20BES P\%2024-3-17.pdf

Jackson, D. L., 2000. Guidance on the interpretation of the Biodiversity Broad Habitat Classification (terrestrial and freshwater types): Definitions and the relationship with other classifications, JNCC Report 307.

Kandziora, M., Burkhard, B., Müller, F., 2013. Mapping provisioning ecosystem services at the local scale using data of varying spatial and temporal resolution. Ecosystem Services 4, 47-59. https://doi.org/10.1016/j.ecoser.2013.04.001 
Kosztra, B., Büttner, G., Hazeu, G., Arnold, S., 2019. Updated CLC illustrated nomenclature guidelines. [Accessed 18 October 2019]. Available at: https://land.copernicus.eu/usercorner/technical-library/corine-land-cover-nomenclatureguidelines/docs/pdf/CLC2018_Nomenclature_illustrated_guide_20190510.pdf

Kreuter, U. P., Harris, H. G., Matlock, M. D., Lacey, R. E., 2001. Change in ecosystem service values in the San Antonio area, Texas. Ecological Economics 39(3), 333-346.

https://doi.org/10.1016/S0921-8009(01)00250-6

Mace, G.M., Hails, R. S., Cryle, P., Harlow, J., Clarke, S. J., 2015. Towards a risk register for natural capital. Journal of Applied Ecology 52, 641-653. https://doi.org/10.1111/1365-2664.12431

Matthews, A., 2013. Greening agricultural payments in the EU's common agricultural policy. Biobased and Applied Economics 2(1), 1-27. http://dx.doi.org/10.13128/BAE-12179

Matthews, E., 1983. Global Vegetation and Land Use: New High-Resolution Data Bases for Climate Studies. Journal of Climate and Applied Meteorology 22, 474-487. https://doi.org/10.1175/15200450(1983)022<0474:GVALUN>2.0.CO;2

Natural Capital Coalition, 2018. This is natural capital 2018. [Accessed 18 October 2019]. Available at: https://naturalcapitalcoalition.org/wp-content/uploads/2018/11/22905_NCC_This-is-NaturalCapital_web.pdf

Natural Capital Committee, 2016. Terms of Reference. [Accessed 17 October 2019]. Available at: https://assets.publishing.service.gov.uk/government/uploads/system/uploads/attachment_data/file/517 123/ncc-terms-of-reference.pdf

Pe'er, G., Dicks, L. V., Visconti, P., Arlettaz, R., Báldi, A., Benton, T. G., Collins, S., Dieterich, M., Gregory, R. D., Hartig, F., Henle, K., Hobson, P. R., Kleijn, D., Neumann, R. K., Robijns, T., Schmidt, J., Shwartz, A., Sutherland, W. J., Turbé, A., Wulf, F., Scott, A. V., 2014. EU agricultural reform fails on biodiversity. Science 344(6188), 1090 - 1092. 10.1126/science.1253425

Pesaresi, M., Ehrlich, D., Ferri, S., Florczyk, A. J., Freire, S., Halkia, M., Julea, A., Kemper, T., Soille, P., Syrris, V., 2016. Operating procedure for the production of the Global Human Settlement Layer from Landsat data of the epochs 1975, 1990, 2000, and 2014; JRC Technical Report EUR 27741. $10.2788 / 253582$

Pesaresi, M., Huadong, G., Blaes, X., Ehrlich, D., Ferri, S., Gueguen, L., Halkia, M., Kauffmann, M., Kemper, T., Lu, L., Marin-Herrera, M. A., Ouzounis, G. K., Scavazzon, M., Soille, P., Syrris, V., Zanchetta, L., 2013. A global human settlement layer from optical HR/VHR RS data: Concept and first results. IEEE Journal of Selected Topics in Applied Earth Observations and Remote Sensing 6(5), 2102-2131. 10.1109/JSTARS.2013.2271445

Philips, J., 2017. Principles of Natural Capital Accounting. [Accessed 18 October 2019]. Available at: https://www.ons.gov.uk/economy/environmentalaccounts/methodologies/principlesofnaturalcapitalac counting

Ready, R., Navrud, S., 2005. Benefit Transfer - The Quick, the Dirty, and the Ugly? Choices 20(3), 195-199. 
Remme, R. P., Edens, B., Schröter, M., Hein, L., 2015. Monetary accounting of ecosystem services: A test case for Limburg province, the Netherlands. Ecological Economics 112, 116-128. https://doi.org/10.1016/j.ecolecon.2015.02.015

Remme, R. P., Schröter, M., Hein, L., 2014. Developing spatial biophysical accounting for multiple ecosystem services. Ecosystem Services 10, 6-18. https://doi.org/10.1016/j.ecoser.2014.07.006

Rowland, C. S.; Morton, R. D.; Carrasco, L.; McShane, G.; O’Neil, A. W.; Wood, C. M., 2017. Land Cover Map 2015 (vector, GB). NERC Environmental Information Data Centre. https://doi.org/10.5285/6c6c9203-7333-4d96-88ab-78925e7a4e73

Rural Payments \& Services, 2016. Payment rates - BPS. [Accessed 18 October 2019]. Available at: https://www.ruralpayments.org/publicsite/futures/topics/all-schemes/basic-payment-scheme/basicpayment-scheme-full-guidance/payment-rates---bps/

Rural Payments \& Services, 2017. Assessing your land eligibility. [Accessed 18 October 2019]. Available at: https://www.ruralpayments.org/publicsite/futures/topics/all-schemes/basic-paymentscheme/basic-payment-scheme-full-guidance/assessing-eligible-land---bps/

Rural Payments Agency, 2018. BPS 2018. [Accessed 18 October 2019]. Available at: https://www.gov.uk/guidance/bps-2018

Rural Payments Agency, Defra, Forestry Commission, Natural England, 2019. Countryside Stewardship. [Accessed 18 October 2019]. Available at: https://www.gov.uk/government/collections/countryside-stewardship-get-paid-for-environmentalland-management

Schägner, J. P., Brander, L., Maes, J., Hartje, V., 2013. Mapping ecosystem services' values: Current practice and future prospects. Ecosystem Services 4, 33-46.

https://doi.org/10.1016/j.ecoser.2013.02.003

Scholefield, P. A., Morton, R. D., Rowland, C. S., Henrys, P. A., Howard, D. C., Norton, L. R., 2016. Woody linear features framework, Great Britain v.1.0.

Seidl, A. F., Moraes, A. S., 2000. Global valuation of ecosystem services: application to the Pantanal da Nhecolandia, Brazil. Ecological Economics 33, 1-6. https://doi.org/10.1016/S09218009(99)00146-9

Spake, R., Bellamy, C., Graham, L. J., Watts, K., Wilson, T., Norton, L. R., Wood, C. M., Schmucki, R., Bullock, J. M., Eigenbrod, F., 2019. An analytical framework for spatially targeted management of natural capital. Nature Sustainability 2, 90-97. https://doi.org/10.1038/s41893-019-0223-4

Sutton, P. C., Costanza, R., 2002. Global estimates of market and non-market values derived from nightie satellite imagery, land cover, and ecosystem service valuation. Ecological Economics 41(3), 509-527. https://doi.org/10.1016/S0921-8009(02)00097-6

Troy, A., Wilson, M. A., 2006. Mapping ecosystem services: Practical challenges and opportunities in linking GIS and value transfer. Ecological Economics 60(2), 435-449.

https://doi.org/10.1016/j.ecolecon.2006.04.007 
Tuck, S. L., Winqvist, C., Mota, F., Ahnström, J., Turnbull, L. A., Bengtsson, J., 2014. Land-use intensity and the effects of organic farming on biodiversity: A hierarchical meta-analysis. Journal of Applied Ecology 51(3), 746-755. https://doi.org/10.1111/1365-2664.12219

UCL Geomatics, 2017. Land Cover CCI: Product User Guide V2. [Accessed 18 October 2019]. Available at: https://www.esa-landcover-cci.org/?q=webfm_send/84

UK National Ecosystem Assessment, 2011. The UK National Ecosystem Assessment: Synthesis of the Key Findings. UNEP-WCMC, Cambridge.

United Nations, 2014. System of Environmental-Economic Accounting 2012: Central Framework, p. $197-198$.

Willis, K. J., Petrokofsky, G., 2017. The natural capital of city trees. Science 356(6336). 374-376. 10.1126/science.aam9724

Winqvist, C., Bengtsson, J., Aavik, T., Berendse, F., Clement, L. W., Eggers, S., Fischer, C., Flohre, A., Geiger, F., Liira, J., Pärt, T., Thies, C., Tscharntke, T., Weisser, W. W., Bommarco, R., 2011. Mixed effects of organic farming and landscape complexity on farmland biodiversity and biological control potential across Europe. Journal of Applied Ecology 48(3), 570-579.

https://doi.org/10.1111/j.1365-2664.2010.01950.x 